\title{
Policy Proposal of the Americans with Disability Act (ADA) Amendments Act of 2008
}

\author{
Sahana Pentyala \\ New Horizon Counseling Center, Smithtown, USA \\ Email: sahanapen@gmail.com
}

How to cite this paper: Pentyala, S. (2021). Policy Proposal of the Americans with Disability Act (ADA) Amendments Act of 2008. Open Journal of Social Sciences, 9, 213-218.

https://doi.org/10.4236/jss.2021.911018

Received: October 6, 2021

Accepted: November 23, 2021

Published: November 26, 2021

Copyright $\odot 2021$ by author(s) and Scientific Research Publishing Inc. This work is licensed under the Creative Commons Attribution International License (CC BY 4.0).

http://creativecommons.org/licenses/by/4.0/

\begin{abstract}
Americans with Disability Act (ADA) and its 2008 Amendment is designed to aid and assist disabled US citizens, yet several inadequacies and discriminatory aspects hinder the intended purpose. In particular, no specific information has been incorporated into the act regarding accommodations in relation to disability and workplace discrimination. With increasing number of unemployed and working US citizens filing for disability benefits, clear mandates need to be defined in order to make the ADA act and its amendments truly serve the purpose of what it is intended to do. In this report, historical and legal aspects of ADA and its 2008 Amendment were researched using published reports, inadequacies related to employment and disability are discussed, and recommendations were proposed to make the ADA, a truly beneficial act that serves the society.
\end{abstract}

\section{Keywords}

Americans with Disability Act, ADA Amendment Act of 2008, Employment, Disability, Discrimination

\section{Introduction}

A nation's progress and prosperity is intricately linked with the ability of its citizen to have a meaningful employment. Particularly, if citizens with disabilities who have the expertise and the knowledge are not supported by government by providing the resources and appropriate employment opportunities, the economic condition of the citizens as well as their self-confidence will suffer, thereby hindering the progress of a nation (Luo and Fan, 2017). The Americans with Disabilities Act (ADA) Amendments act was passed in 2008 to rectify inconsistencies written in the ADA of 1990 . The ADA was intended to help people with disabilities and not to discriminate irrespective of the type of disability. The in- 
consistencies related to ADA came to light when two major court cases were taken up for review in the Supreme Court. They were: "Sutton v. United Air Lines, Inc., 527 U.S. 471 (1999)" and "Toyota Motor Manufacturing, Kentucky, Inc. v. Williams, 534 U.S. 184 (2002)". Because of these two Supreme Court cases, it was deemed that the ADA had a loophole, where a person can avail disability benefits based on the interpretation by a court ruling. As a result, the ADA Amendments act was passed in 2008 making the act strict in terms of how disability is evaluated.

\section{Problem Statement}

Although restrictions and guidelines have been incorporated, the ADA Amendments Act of 2008 failed to recognize that there are still inadequacies that affect many citizens who have a disability which is related to their workspace. The ADA of 1990 tried to cover the issue employment in Title 1, where it states that any citizen with a disability can find a job without being discriminated (ADA National Network, 2020). However, the ADA Amendments Act of 2008 implemented changes in the Equal employment and Opportunities commission's role which contradicts Title 1 about employment and disability benefits. An aspect that is incorporated in the ADA Amendments Act is that, a disabled person cannot file a lawsuit under the terms of reasonable accommodation but can file under any other discriminatory reason (ADA National network, 2020).

\section{Proposed Policy Solution}

In order to understand the US ADA policy proposal, it is important to understand the livelihood issues being faced by people with disability. In the past 50 years, the number of people tripled in terms of disability (Schwabish, 2017) and the numbers are continually rising. The National Center on Birth Defects and Developmental Disabilities, Centers for Disease Control and Prevention (2019) completed a survey and found that around 61 million people in the United States have been considered as having a disability. This number is from the people who participated in the survey, and there might be even more disabled people who may not have participated in the survey. As of 2019, 1 million people have a severe disability, 2 million people have some sort of limitation as a result of their disability, and 5 million people are younger generation (Dreamscape Foundation, 2019). It is also important to acknowledge that people with a disability have a hard time finding jobs or even get accommodations. The people who are considered in the disability statistics can be eligible for jobs depending on what the disability is but are not able procure employment due to the discrimination that they experience the first time they attend an interview. Specifically, when we discuss about New York City, about $6.8 \%$ of the population has a disability and they are under the age of 65 (United States Census Bureau, 2019). This is just a portion of New York State; however, it is important to recognize that this is a reality in many other states and only specific portions of the states are accounted 
for in statistics. Overall, in the United States, "among persons with a disability, Blacks had a higher unemployment rate in 2019 (11.8 percent) than Hispanics (8.6 percent), Asians (6.7 percent), and Whites (6.6 percent)" (U.S. Department of Labor, 2020). According to Bhattacharya and Long (2015), people who have disabilities get paid less than non-disabled people and they also noticed how employment rates from the 1990 's have decreased from $50 \%$ to $41 \%$. This is an extraordinary change considering the rise in the number of people who qualify for disabilities. It was reported in 2019, that the rate of unemployment for disabled people was $9.2 \%$ whereas people who did not have a disability had an unemployment rate of $4.2 \%$ (Draeger, 2019). While the constitution says that everyone is equal and disabled individuals should not be discriminated, it seems that citizens who are considered disabled are not getting a fair chance to procure employment.

The ADA as well as the associated Amendment Act is in accordance with the Triple Aim discussed by Stanhope and Straussner (2018). The triple aim focuses on "improving population health, reducing the cost of care, and improving the experience of care". Not being able to find employment can be very stressful for people. It can affect their health both mentally and physically. Physical symptoms of stress include headaches, an upset stomach, elevated blood pressure and chest pain, while some of the symptoms that are related to mental health are depression, panic attacks and anxiety (Cleveland Clinic, 2020). By decreasing stress, the population's health can be improved. As far as reducing the cost of care, providing any type of social service will cost money. Health care is a major economic burden on the society. As doctors go through most likely scenarios of what is causing a person to have certain symptoms, patients are subjected to many expensive tests before the root cause of stress is identified. Therefore, if the stress is decreased, the burden on health care decreases, thereby reducing the economic burden on the society. Hence, by decreasing stressful symptoms, citizens won't have to seek many of the social services. This can encourage these individuals actively looking for employment and negotiate fair deals with their employers regarding their benefits. All these outcomes are in accordance with Stanhope's Triple Aim of increasing population health, reducing care costs, and enhancing care experience.

Observing the challenges faced by people with disabilities as a counselor in Adult Day Care Center, Veterans Home and Counseling Center, I am proposing to change or revise aspects of the ADA Amendments Act of 2008 in order to make the ADA policy more effective, which will cater to the many number of people who are affected by it. I would like to address the loophole of how people are discriminated in the workplace based on their disability and how they are accommodated in the workforce to perform a designated job. Unable to provide proper accommodation in the workplace itself is disabling for already disabled individual. As the number of disabled people is on the rise in the United States, it is critical to make sure that appropriate accommodations to individuals with 
disability at workplace should be provided. Hence, I am proposing that the Act incorporates a revision that insists that employees with disability must be provided reasonable accommodation in the workplace, and they can pursue legal action if the employer does not meet this criterion. By strictly enforcing this rule, more employment opportunities will open for people who have a disability. The more the disabled individuals enter the workforce, the more the population health increases, and this in turn can reduce the burden on the social services.

\section{Implementation Strategy and Challenges}

In order to ensure the provision of providing reasonable accommodations at workplace for disabled persons be incorporated in the ADA act, a logical step-by-step approach might be needed. For example, if this initiative is taken up in New York (NY) state, the Act and its provisions and revisions should be discussed and passed by NY state Assembly and then by the NY State Senate. Once the bill is approved and passed in these two legislative bodies, then, the NY State governor signs this ratification into State law (NYC Mayor's Office of Intergovernmental Affairs, 2014). The NY State governor can send this revision of the Act to the US Congress through NY state Congressional delegates for sponsoring. The proposal will be first taken up by the US House of Representatives and investigated by a committee before taking up on the floor for voting. If 218 of 435 people in the House approve, then the bill can be sent to the US Senate. Fifty one senators out of one hundred have to approve the bill and then it will be taken up by a select committee consisting of the House and Senate. Members of this committee will revise it and then send it back to the house and senate for final approval. Once this is accomplished, the president will have 10 days to approve or veto the bill (U.S. House of Representatives, n.d.). The whole process is time consuming and should get bipartisan support. Any change in legislation or enactment of new legislation cannot be just accomplished by the will of elected officials or their pen strokes, but it is in the hands of the citizens who has to raise their voice and demand a change in order to bring social justice. If the citizens have the will, changing the legislation and enacting the law will be much easier to accomplish.

There are a few challenges that the ADA Amendments act of 2008 revision may cause. The first aspect will be with regards to feasibility where skeptics will take advantage. Feasibility really depends on what an entity can afford to do. Some businesses will have enough money and resources to accommodate their employees with disability while some may not. Also, the idea of trying to accommodate their employees can put the employers in a situation where the companies do not make as much profit as they want to. To counteract this challenge, while incorporating changes in the Act, it should be mandated that the federal or state government should provide incentives to the employer to accommodate at least a certain percentage of employees with disabilities. This will encourage the employers to proactively help their employees with disabilities, 
reducing the burden financially as well as promoting the well-being of their institute and the workforce. The Federal and State governments can year mark funds specifically for this initiative and this will help in the long run to reduce the burden on the social services. Another challenge to the revision that I am proposing is related to individuals who are already employed in the company but suddenly become disabled. Some companies fire these individuals who are disabled on the job as they cannot accommodate them due to their specific disability. So, the revisions to the Act should have a provision where the employee who is disabled while in job instead of being fired, be moved to a different position that is more accommodating for their disability and something that is mutually agreed upon. By implementing this, employees will not lose their jobs, nor will the business lose anything substantial as they can still retain their loyal employee, which in turn might increase the production as well as revenues of the company.

Mental health issues cause devastating effects on a disabled individual. With the added burden of unemployment, which are compounded by economic struggles, people with disability are under tremendous mental pressure. This is a challenge that is not really recognized. I am proposing that the ADA act should have provisions for providing mental health care to individuals in need. Trained mental health care providers and social workers should be supported in the ADA Act to cater to the needs of the unemployed disabled citizens to effectively rehabilitate them.

\section{Conclusion}

In this report, the US ADA act and its 2008 Amendment were discussed highlighting the problems and challenges associated with implementing this act. Remedies were proposed to overcome these aspects based upon the experience gained by working with unemployed individuals with disability. It is the will of the people collectively, that can make any type of moral and ethical virtue into an enforceable law, which in turn will be of the greatest help to the citizens who are being forgotten or not being taken care of. Social workers role is extremely critical in this process and it is fulfilling as well as uplifting to be able to help others in any which way one can so that a healthy and happy society prevails.

\section{Conflicts of Interest}

The author declares no conflicts of interest regarding the publication of this paper.

\section{References}

ADA National Network (2020, March). An Employee View of the Changes from the ADA Amendments Act. https://adata.org/factsheet/employee-view-ada

Bhattacharya, A. \& Long, H. (2015, July 26). America Still Leaves the Disabled Behind. https://money.cnn.com/2015/07/26/news/economy/americans-with-disabilities-act-pro 
blems-remain/

Cleveland Clinic (2020). Stress: Signs, Symptoms, Management \& Prevention. https://my.clevelandclinic.org/health/articles/11874-stress

Draeger, S. (2019, March). Employing People with Disabilities. https://www.ncsl.org/research/labor-and-employment/employing-people-with-disabilit ies-legisbrief.aspx

Dreamscape Foundation (2019). Why Accessibility? https://dreamscapefoundation.org/why-accessibility/?gclid=EAIaIQobChMI-7zMoOe m6AIVBOiGCh0CLA4-EAAYASAAEgI-YfD_BwE

Luo, X., \& Fan, Y. (2017). Rethinking the Government Role of Promoting Employment Policies for Persons with Disabilities: A Case Study of Anhui Province in China. Open Journal of Social Sciences, 5, 209-219. https://doi.org/10.4236/jss.2017.58017

National Center on Birth Defects and Developmental Disabilities, Centers for Disease Control and Prevention (2019, September 9). Disability Impacts All of Us Infographic. https://www.cdc.gov/ncbddd/disabilityandhealth/infographic-disability-impacts-all.ht $\underline{\mathrm{ml}}$

NYC Mayor's Office of Intergovernmental Affairs (2014). State Legislative Process. http://www.nyc.gov/html/moiga/pages/state/process.shtml

Schwabish, J. (2017, September 12). 11 Charts about the Social Security Disability Insurance Program.

https://www.urban.org/features/11-charts-about-social-security-disability-insurance-pr ogram

Stanhope, V., \& Straussner, S. L. A. (Eds.) (2018). Social Work and Integrated Healthcare: From Policy to Practice and Back. Oxford University Press.

U.S. Department of Labor (2020, February 26). Persons with a Disability: Labor Force Characteristics-2019. https://www.bls.gov/news.release/pdf/disabl.nr0.pdf

U.S. House of Representatives (n.d.). The Legislative Process. https://www.house.gov/the-house-explained/the-legislative-process

United States Census Bureau (2019). U.S. Census Bureau Quick Facts. New York. https://www.census.gov/quickfacts/NY 